\title{
Abnormal uterine bleeding in relation to thyroid dysfunction
}

\author{
H. C. Sudha*, K. M. Sunanda, Anitha G. S.
}

Department of Obstetrics and Gynecology, Bangalore Medical College and Research Institute, Bengaluru, Karnataka, India

Received: 05 August 2018

Accepted: 27 September 2018

*Correspondence:

Dr. H. C. Sudha,

E-mail: drhcsudha@gmail.com

Copyright: (c) the author(s), publisher and licensee Medip Academy. This is an open-access article distributed under the terms of the Creative Commons Attribution Non-Commercial License, which permits unrestricted non-commercial use, distribution, and reproduction in any medium, provided the original work is properly cited.

\section{ABSTRACT}

Background: Abnormal uterine bleeding is an abnormal bleeding from the uterus in absence of any organic disease of genital tract and demonstrable extra genital causes. Thyroid dysfunction is marked by large number of menstrual abnormalities. This study is aimed at detecting thyroid dysfunction in patients with provisional diagnosis of AUB (abnormal uterine bleeding).and refer positive cases to physician for further management.

Methods: All patients from are from puberty to pre-menopausal age groups, presenting as menoraghia, metrorragia, polymenorrhoea, polymenorragia, hypomenorrhoea, and acyclical bleeding. Onset, duration, amount of bleeding, complaints related to thyroid dysfunction was noted in detail. A thorough clinical examination including general physical examination, neck examination, systemic and gynecological examination was carried out, with special reference to thyroid dysfunction. A provisional clinical diagnosis of DUB was made. Patients with clinical signs and symptoms of thyroid disease were excluded. All these patients were subjected to routine investigations like $\mathrm{Hb} \%$, blood counts, urine routine, and bleeding and clotting time to rule out coagulation defects. Then all were subjected for serum T3, T4, and TSH estimation. Patients were then grouped into 4 categories: euthyroid, subclinical lhypothyroid, hypothyroid, and hyperthyroid. Patients who had thyroid disease, on hormonal treatment, IUCD users, and bleeding disorders were excluded.

Results: Among 100 patients studied with abnormal uterine bleeding, patients were distributed according to age groups from puberty to perimenopause age. Majority of patients belongs to 31-40 years of age about $40 \%$ and the least age group were between $41-45$ years of age.(7\%).Among different parity status AUB was more common among para three patients(26\%). Out of 100 patients, $32 \%$ of patients had thyroid dysfunction of which $16 \%$ of patients had subclinical hypothyroidism. $15 \%$ of patients had hypothyroidism and only $2 \%$ of patients had hyperthyroidism. The commonest bleeding abnormality in AUB were polymenorrhoea (30\%) and menorrhagia (35\%). All hyperthyroid cases were oligomenorrhoeic.

Conclusions: This study concludes that thyroid dysfunction should be considered as an important etiological factor for menstrual abnormality. The biochemical evaluation of T3, T4, and TSH estimations should be made mandatory in AUB cases to detect apparent and occult thyroid dysfunction.

Keywords: AUB, DUB, Hyperthyroid, Hypothyroid, Inter menstrual bleeding, Menorrhagia, Metrorragia, Polymenorrhoea, Thyroid, TSH

\section{INTRODUCTION}

Abnormal uterine bleeding is a bleeding from the uterus in absence of organic disease of genital tract and demonstrable extra genital cause. AUB accounts $10 \%$ of gynecological related complaints. Thyroid dysfunction is also marked by large numbers in relation to menstrual abnormalities. $^{2}$ 
Regular cyclic menstruation results from the choreographed relationship between the endomertium and its regulating factors1.Changes in either of these frequently results in abnormal bleeding.It affects upto one third of women of child bearing age. ${ }^{3}$

Normal reproductive behavior and physiology is dependent on having essentially normal levels of Thyroid hormone. Thyroid hormones play an important role in normal reproductive function both through direct effects on the ovaries and indirectly by interacting with sex hormone binding proteins., ${ }^{4,5}$

Diseases of thyroid gland are among the most prevalent disorders worldwide second only to diabetes. ${ }^{6}$ Both hypo as well as hyper thyroidism are associated with variety of changes in reproductive function including delayed onset of puberty, anovulatory cycles and abnormally high fetal wastage. ${ }^{7}$ Clinical experienceshows increased menstrual flow to be the most common reproductive manifestation of hypothyroidism.

Although the occurrence of menstrual disturbances in hypothyroid women has been documented, the number of hypothyroid patients originally requiring treatment for menorragia has not been carefully elicited. ${ }^{8}$ Moreover, majority of the cases have subclinical hypothyroidism and easily pass unrecognized. Danese et al recommened hypothyroidism is frequent enough to warrant consideration in older women. ${ }^{9}$

The introduction of serum thyroxine (T3) and thyroid stimulating hormone (TSH). Radio immunoassays has increased the sensitivity and specificity of thyroid function testing. The serum TSH assay has been shown to be a sensitive indicator of diminished thyroid function reserve, since TSH levels become elevated before circulating serum thyroxine levels fall below normal range. ${ }^{10}$

Hence the study is to evaluate the thyroid function in patients having abnormal uterine bleeding from puberty to premenopausal age groups. The objective of the present study was to evaluate and detect the thyroid dysfunction in patients with AUB, and to refer positive cases to physician for further management.

\section{METHODS}

Present study is to establish the role of thyroid dysfunction in relation to menstrual disturbances. This study was carried out in the department of obstetrics and gynecology at vanivilas hospital, a tertiary care centre attached to Bangalore Medical College and Research Centre, Bengaluru.

100 women who were given clinically the provisional diagnosis of dysfunctional uterine bleeding. This is a prospective done from April-2017 to March-2018.
All patients from are from puberty to pre-menopausal age groups, presenting as menoraghia, metrorragia, polymenorrhoea, polymenorragia, hypomenorrhoea, and acyclical bleeding. A detailed history was obtained with special reference to age and bleeding pattern, onset, duration, amount of bleeding, complaints related to thyroid dysfunction were noted.

A thorough clinical examination including general physical examination, neck examination, systemic and gynecological examination was carried out, with special reference to thyroid dysfunction. A provisional clinical diagnosis of DUB was made. Patients with clinical signs and symptoms of thyroid disease were excluded.

All these patients were subjected to routine investigations like $\mathrm{Hb} \%$, blood counts, urine. routine, and bleeding and clotting time to rule out coagulation defects. Then all were subjected for serum T3, T4, and TSH estimation. Patients were then grouped into 4 categories: Euthyroid, Subclinical hypothyroid, Hypothyroid, and Hyperthyroid. Patients who had thyroid disease, on hormonal treatment, IUCD users, and bleeding disorders were excluded.

\section{Inclusion criteria}

- All cases provisionally diagnosed to have DUB from puberty to pre-menopause age groups.

- All patients who had major complaints of menstrual disturbances like menorragia poly menorrhea, polymenorragia, metrorragia, and intermenstrual bleeding.

\section{Exclusion criteria}

- Patients who were on drugs or hormones, IUCD users, with overt clinical symptoms of thyroid dysfunction was excluded. History of bleeding disorders was also excluded.

\section{RESULTS}

Table 1: Distribution of patients according to age.

\begin{tabular}{|l|l|l|}
\hline Age in years & No. of cases & Percentage \\
\hline$<20$ years & 18 & 18 \\
\hline 21-30 years & 35 & 35 \\
\hline 31-40 years & 40 & 40 \\
\hline 41-45 years & 07 & 7 \\
\hline Total & 100 & 100 \\
\hline
\end{tabular}

Maximum number of cases were 40 between the age group of 31 to 40 years whereas the least no of cases were 7 between age group of 41-45 years.

Table 2 represents relationship AUB with parity. Among 100 cases of AUB, 11 were unmarried,7 were nulliparous, 10 were para one, 25 were para two, para 3 were 26 , while para four were 21 . In this study maximum number 
of cases were multiparous $26 \%$ while minimum no of cases were nulliparas.

Table 2: Distribution of patients according to parity.

\begin{tabular}{|lll|}
\hline Parity & No. of patients & Percentage \\
\hline Unmarried & 11 & 11 \\
\hline Nullipara & 07 & 07 \\
\hline 1 & 10 & 10 \\
\hline s2 & 25 & 25 \\
\hline 3 & 26 & 26 \\
\hline 4 & 21 & 21 \\
\hline & 100 & 100 \\
\hline
\end{tabular}

Table 3 shows bleeding patterns in AUB the commonest bleeding pattern is menorraghia $35 \%$, followed by polymenorrhoea $30 \%$.

The least bleeding pattern is inter menstrual bleeding $2 \%$. Patients with age less than 20 years, the most common bleeding pattern was menorrhagia $(55 \%)$ followed by polymenorrhea $(22.2 \%)$ and also polymenorrhagia $(22.2 \%)$.

Table 3: Distribution of patients according to symptoms.

\begin{tabular}{|lll|}
\hline Type of blecding & No. of cases & Percentage \\
\hline Hypomenorrhoea & 3 & 3 \\
\hline Menorraghia & 35 & 35 \\
\hline Intermenstrual bleeding & 2 & 2 \\
\hline Polymenorraghia & 20 & 20 \\
\hline Polymenorrhoea & 30 & 30 \\
\hline Acyclical bleeding & 10 & 10 \\
\hline & 100 & 100 \\
\hline
\end{tabular}

In this study menorrhagia is the common bleeding pattern from puberty age groups to pre-menopausal age. The least bleeding pattern was intermenstrual bleeding (metrorrhagia) and acyclical bleeding.

Table 4: Distribution of patients according to age groups and bleeding patterns.

\begin{tabular}{|c|c|c|c|c|c|c|c|c|c|c|c|c|}
\hline \multirow{2}{*}{$\begin{array}{l}\text { Age in } \\
\text { years } \\
<20\end{array}$} & \multirow{2}{*}{$\begin{array}{l}\text { No. of } \\
\text { Cases } \\
18\end{array}$} & \multirow{2}{*}{$\begin{array}{l}\text { Hypo- } \\
\text { menorrhea } \\
0\end{array}$} & \multicolumn{2}{|c|}{ Menorrhagia } & \multicolumn{2}{|c|}{$\begin{array}{l}\text { Metrorraghia } \\
\text { /inter } \\
\text { menstrual } \\
\text { bleeding }\end{array}$} & \multicolumn{2}{|c|}{$\begin{array}{l}\text { Poly } \\
\text { menorrhea }\end{array}$} & \multicolumn{2}{|c|}{$\begin{array}{l}\text { Poly- } \\
\text { menorrhagia }\end{array}$} & \multicolumn{2}{|c|}{$\begin{array}{l}\text { Acyclical } \\
\text { bleeding }\end{array}$} \\
\hline & & & 10 & 55.5 & 0 & & 4 & 22.2 & 4 & 22.2 & 0 & - \\
\hline $21-30$ & 35 & 0 & 18 & 51.4 & 0 & & 7 & 20 & 8 & 22.8 & 2 & 5.7 \\
\hline $31-40$ & 40 & $3(75 \%)$ & 18 & 45 & 1 & $2.5 \%$ & 10 & 25 & 6 & 15 & 5 & 12.5 \\
\hline $41-45$ & 7 & 0 & 2 & 28.5 & 1 & $14.2 \%$ & 2 & 28.5 & 1 & 14.2 & 1 & 14.2 \\
\hline Total & 100 & & & & & & & & & & & \\
\hline
\end{tabular}

Table 5 shows majority of cases were euthyroid (62\%) whereas, $16 \%$ of patients had profound hypothyroidism with high levels of TSH. $12 \%$ of the patients had sub clinical hypothyroid with the history of AUB, while only $2 \%$ of patients had hyperthyroidism, although they were clinically asymptomatic.

Table 5: Distribution of patients according to thyroid function.

\begin{tabular}{|lll|}
\hline Thyroid Function & No. of cases & Percentage \\
\hline Euthyroid & 70 & 62 \\
\hline Hypothyroid & 16 & 16 \\
\hline Sub clinical hypothyroid & 12 & 12 \\
\hline Hyperthyroid & 02 & 2 \\
\hline Total & 100 & \\
\hline
\end{tabular}

Table 6 represents the relationship of parity to thyroid dysfunction in patients with provisional diagnosis of DUB. Thyroid dysfunction was commonest among unmarried patients about $54.5 \%$ followed by multiparous patients $42.8 \%$. The thyroid dysfunction was least common in primipara patients with $20 \%$. The difference in thyroid function in individual type of parity is not statistically significant.

Table 7 shows the relationship of thyroid dysfunction to different age groups. Thyroid dysfunction was commonest in age groups between $31-40$ years $30 \%$. This shows thyroid dysfunction becomes common as patients age advances. Thyroid dysfunction was least common between 20-30 years of age groups. The difference in thyroid functioning in individual age groups is not statistically significant.

Table 8 explains the relationship of hypothyroidism, hyperthyroidism, and subclinical hypothyroidism to different types of clinically diagnosed AUB. Patients with menorragia, $11.4 \%$ had hypothyroidism while in polymenorrhoea and polymenorrhagia patients $25 \%$ and $20 \%$ were hypothyroid respectively.

Patients who were subclinically hypothyroid were commonly presenting as polymenorragia and menorragia $66.6 \%$ and $74.2 \%$ respectively. The least combination was oligo/ hypomenorrhoea patients who had normal 
Table 6: Thyroid dysfunction in relation to parity.

\begin{tabular}{|llllllll|}
\hline Parity & $\begin{array}{l}\text { No. of } \\
\text { cases }\end{array}$ & Euthyroid & Hypothyroid & $\begin{array}{l}\text { Sub clinically } \\
\text { pothyroid }\end{array}$ & Hyperthyroid & $\begin{array}{l}\text { Total thyroid } \\
\text { dysfunction }\end{array}$ & \% \\
\hline Unmarried & 11 & 6 & 3 & 3 & - & 6 & 54.5 \\
\hline 0 & 07 & 4 & 2 & 1 & - & 3 & 42.8 \\
\hline 1 & 10 & 8 & 1 & 0 & 1 & 2 & 20 \\
\hline 2 & 25 & 17 & 3 & 5 & - & 10 & 32 \\
\hline 3 & 26 & 16 & 2 & 7 & 1 & 4 & 38.4 \\
\hline 4 & 21 & 17 & 2 & 1 & & 33 & 19 \\
\hline Total & 100 & & & & & 1 & \\
\hline
\end{tabular}

Table 7: Thyroid dysfunction in different age groups.

\begin{tabular}{|lllllll|}
$\begin{array}{l}\text { Age in years } \\
<20\end{array}$ & $\begin{array}{l}\text { No. of } \\
\text { cases }\end{array}$ & Euthyroid & Hypohyroid & $\begin{array}{l}\text { Subclinical hypo } \\
\text { thyroid }\end{array}$ & Hyper thyroid & Total thyroid \\
\hline 21-30 years & 35 & 25 & 6 & 3 & 1 & 10 \\
\hline 31-40years & 40 & 28 & 3 & 8 & 1 & 12 \\
\hline 41-45 years & 7 & 6 & 0 & 1 & 0 & 1 \\
\hline Total & 100 & 74 & 10 & 14 & 2 & 26 \\
\hline
\end{tabular}

Table 8: Bleeding pattern in hypothyroidism and hyperthyroidism.

\begin{tabular}{|c|c|c|c|c|c|c|c|c|c|}
\hline Type of bleeding & $\begin{array}{l}\text { No. of } \\
\text { cases }\end{array}$ & Euthyroid & & $\begin{array}{l}\text { Hypo } \\
\text { thyroid }\end{array}$ & $\%$ & $\begin{array}{l}\text { Sub clinical } \\
\text { hypo thyroid }\end{array}$ & $\%$ & $\begin{array}{l}\text { Hyper } \\
\text { thyroid }\end{array}$ & $\%$ \\
\hline Hypomenorrhoea & 3 & 2 & $66.6 \%$ & - & - & - & - & 1 & 33.3 \\
\hline Menorrhagia & 35 & 26 & $74.2 \%$ & 4 & 11.4 & 5 & 14.5 & - & - \\
\hline $\begin{array}{l}\text { Inter menstrual } \\
\text { bleeding }\end{array}$ & 2 & 2 & $100 \%$ & - & - & - & - & - & - \\
\hline Polymenorrhoea & 20 & 10 & $50 \%$ & 5 & 25 & 5 & 25 & 1 & 5 \\
\hline Polymenorrhagia & 30 & 20 & $66.6 \%$ & 6 & 20 & 3 & 10 & - & - \\
\hline Acyclical bleeding & 10 & 7 & $70 \%$ & - & - & 3 & 30 & - & - \\
\hline
\end{tabular}

Table 9: TSH levels and different bleeding patterns.

\begin{tabular}{|llllllll|}
\hline TSH levels & $\begin{array}{l}\text { No. of } \\
\text { cases }\end{array}$ & $\begin{array}{l}\text { Hypo } \\
\text { menorrhoea }\end{array}$ & Menorragia & Metrorragia & $\begin{array}{l}\text { Poly } \\
\text { menorrhoea }\end{array}$ & $\begin{array}{l}\text { Poly } \\
\text { menorrhagia }\end{array}$ & $\begin{array}{c}\text { Acyclical } \\
\text { bleeding }\end{array}$ \\
\hline$<0.39 \mathrm{Mu} / 1$ & 2 & 1 & - & - & 1 & - & - \\
\hline $0.4-5.5 \mathrm{Mu} / 1$ & 67 & 2 & 2 & 26 & 20 & 10 & 7 \\
\hline $5.7-50 \mathrm{mu} / 1$ & 25 & 1 & 1 & 8 & 8 & 5 & 3 \\
\hline$>50 \mathrm{Mu} / 1$ & 6 & - & - & 4 & 2 & - & - \\
\hline
\end{tabular}

Table 9 signifies the relation of TSH levels to different types of bleeding pattern. Patients with TSH levels of $<0.39 \mathrm{mu} / 1$ all of them presented with symptoms of oligomenorrhoea.

Patients with TSH levels moderately elevated $5.7-<50$ as seen in subclinical hypothyroidism. Patients with TSH levels $>50 \mathrm{mu} / \mathrm{l}$ presented with inter menstrual and polymenorrhoea.
Table 10: Age pattern in dub with thyroid dysfunction.

\begin{tabular}{|lll|}
\hline Age in years & No. of patients & Percentage \\
\hline$<20$ years & 8 & 25 \\
\hline 21-30 years & 8 & 25 \\
\hline $31-40$ years & 11 & 34.3 \\
\hline $41-45$ years & 5 & 15.6 \\
\hline
\end{tabular}


Table 10 thyroid dysfunction in relation to age pattern. According to this, thyroid dysfunction was seen more commonly in the age groups between 31 to 40 years which amounts to $34.3 \%$ which is less than 25 years at $25 \%$. The least was seen in women between $41-45$ years of age. The present study type of menstrual abnormality, hypothyroidism was seen in $17.2 \%$ of cases. C. D. Doifode study also shows menorragia/ polymenorrhoea as common bleeding pattern. In C. D. Doifode et al 2001 study also shows hypothyroidism in $28.1 \%$ of cases.

Table 11: Hypothyroidism in different bleeding patterns.

\begin{tabular}{|lll|}
\hline Study & $\begin{array}{l}\text { No. of pts presenting } \\
\text { with menorragia/ } \\
\text { polymenorrhoea/ } \\
\text { polymenorragia }\end{array}$ & $\begin{array}{l}\text { Patients who had } \\
\text { hypothyroidism }\end{array}$ \\
$\begin{array}{l}\text { Present } \\
\text { study }\end{array}$ & $87(74.2)$ & $15(17.2)$ \\
\hline $\begin{array}{l}\text { Doifode CD } \\
\text { et al }\end{array}$ & 213 & $60(28.1)$ \\
\hline
\end{tabular}

The present study type of menstrual abnormality, hypothyroidism was seen in $17.2 \%$ of cases. Doifode CD study also shows menorrhagia/ polymenorrhoea as common bleeding pattern. In Doifode CD et al study also shows hypothyroidism in $28.1 \%$ of cases.

Table 12: Menorrhagia in hypothyroidism.

\begin{tabular}{|c|c|}
\hline Authors & Menorrhagia \\
\hline Doifode CD et al ${ }^{11}$ & $63.30 \%$ \\
\hline Singh et $\mathrm{al}^{7}$ & $44.40 \%$ \\
\hline Willansky and Bernard ${ }^{8}$ & $100 \%$ \\
\hline Present study & $91.4 \%$ \\
\hline
\end{tabular}

This is one more study to compare that menorrhagia is the commonest symptom in hypothyroidism. Doifode CD shows $63.3 \%$ of menorrhagia. Cases among all DUB cases. Singh et al shows $44.4 \%$ of menorragic cases whereas, in Willansky and Bernard 1989 shows 100\% menorragia as symptom. Present study also shows $91.4 \%$ of cases of menorragia as a common complaint in patients with hypothyroidism.

\section{DISCUSSION}

This is prospective case control study done at Vanivilas Hospital, Bangalore Medical College and Research Institute, Bengaluru, from April 2017 to March 2018. In this study, 100 women were taken who had AUB from puberty to perimenopause age groups i,e. below $20 \mathrm{yrs}$, 21-30 yrs, 31-40 yrs, 41-45 yrs. Maximum number of patients in this study belongs to the age groups of 31-40 years. In present study, patients were grouped according to parity unmarried, nulliparous, para 1, para 2, para 3, para 4 and above. The commonest symptom was menorragia in 35 patients, polymenorrhoea in 30 patients, polymenorragia in 20 patients, and 10 patients had acyclical bleeding. 2 patients had intermenstrual and oligomenorrhoea. In a study done by Charusheela D doifode et al 200111 also, maximum number of patients belonged to the age group 31-40 yrs. $15 \%$ were unmarried, $6.67 \%$ were nulliparous, $33.33 \%$ para $1,15 \%$ were para 2 , and $20 \%$ were para 3 , patients who had menorrhagia were $63.3 \%$ and $23.33 \%$ had polymenorrhagia.

The maximum number of patients who had total thyroid dysfunction $(54.5 \%)$ were unmarried. Least thyroid dysfunction was seen among para 4 and above (19.0\%). While nulligravida $(42.8 \%)$, para $1(20 \%)$, para 2 were (32\%) and $38.4 \%$ were para 3 patients who had thyroid dysfunction. In this study, thyroid dysfunction was common in the age groups of 31-40 years (30\%), $16.6 \%$ in less than 20 years, $28.5 \%$ in $21-30$ years and it was least in patients more than 40 years $(14.2 \%)$.

In present study, commonest menstrual abnormality seen in hypothyroidism was polymenorrhoea $(25 \%)$, followed by polymenorragia (20\%), while $11.4 \%$ had menorragia. Subclinical hypothyroidism was seen in $14 \%$ of cases with polymenorragia of which $30 \%$ of patients were between 32-40 yrs. There were only 3 cases of oligomenorrhoea of which 2 were euthyroid and one had hyperthyroidism.In a study done by SINGH et al7s $44.4 \%$ menoragia in hypothyroidism. In a study done bywilansky and Bernard8 $100 \%$ cases had menorragia in hypothyroidism. In present study sub clinical hypothyroidism was seen in $74.4 \%$ of menorragic cases.In study done by Jaydev Mukerjee et al $12100 \%$ menorragia. In present study 3 cases were oligomenorrhoea out of which only one was hyperthyroid. In study done by kalyanimukerji et al 1310 cases of oligomenorrhoea, 6 pts had hyperthyroidism. Lakshmisingh et al study 7 also shows hyperthyroid with oligomenorrhoea.

These results were consistent with most of the similar studies. Both subclinical and profound hypothyroid cases were the commonest thyroid dysfunction and menorragia was their commonest menstrual abnormality.

\section{CONCLUSION}

This study concludes that biochemical evaluation of thyroid functioning should be made mandatory in all provisionally diagnosed cases of abnormal uterine bleeding to detect thyroid dysfunction.

\section{Funding: No funding sources \\ Conflict of interest: None declared}

Ethical approval: The study was approved by the Institutional Ethics Committee

\section{REFERENCES}

1. Davey da, Dewhurst, text book of Obstetrics and Gynecology. chapter 40,5th ed,1990; pp 590-600. 
2. William J Butler. Normal and abnormal uterine bleeding. In: Telendes Operative Gynecology. $8^{\text {th }}$ ed; 1996: 453-473.

3. Nicholson WK, Ellison SA, Grason H, Powe NR. Of ambulatory care use for gynecologic conditions; A national study. Am J Obstet Gynecol. 2001;184(4):523-30.

4. Topper YJ. Multiple hormone interactions in the development of mammary gland in vitro. InProceedings of the 1969 Laurentian Hormone Conference 1970. pp. 287-308.

5. Poppe K, Glinoer D. Thyroid autoimmunity and hypothyroidism before and during pregnancy. Human Reproduct Update. 2003;9(2):149-61.

6. Mohanty S, Amruthlal W, Reddy GC, Kusumanjali G, Kanagasabapathy AS, Rao P. Diagnostic strategies for subclinical hypothyroidism. Indian J Clinic Biochem. 2008;23(3):279.

7. Singh L, Agarwai CG, Chowdhary SR, Mehra P, Khare R. Thyroid profile in infertile women. J Obstet Gynecol India. 1990;40:248.

8. Wilansky DL, Greisman B. Early hypothyroidism in patients with menorrhagia. Am J Obstet Gynecol. 1989;160(3):673-7.
9. Danese MD, Powe NR, Sawin CT, Ladenson PW. Screening for mild thyroid failure at the periodic health examination: a decision and cost-effectiveness analysis. Jama. 1996;276(4):285-92.

10. Ingbar $\mathrm{SH}$, Wiwams $\mathrm{RH}$. Text book of endocrinology. $7^{\text {th }}$ ed; 1985:792.

11. Doifode CD, Fernades K. Study of Thyroid dysfunction in patients with DUB. J Obstet Gynecol India. 2001:51(2);93-5.

12. Mukherjee J, Chowdhary NR. A review of 70 cases of puberty menorrhagia. J Obst and Gynaec of India. 1986:121.

13. Mukherjee K, Ghosh AK. Thyroid prolactin related menstruation. J Obstet Gynecol India. 1985;35:5492.

Cite this article as: Sudha HC, Sunanda KM, Anitha GS. Abnormal uterine bleeding in relation to thyroid dysfunction. Int J Reprod Contracept Obstet Gynecol 2018;7:4525-30. 